\title{
Hydrothermal pits in the biogenic sediments of the equatorial Pacific Ocean
}

\section{Ted C. Moore Jr.}

Department of Geological Sciences, University of Michigan, 2534 C.C. Little Building, 425 East University Avenue, Ann Arbor, Michigan 48109-1005, USA (tedmoore@umich.edu)

\section{Neil C. Mitchell}

School of Earth, Atmospheric and Environmental Sciences, University of Manchester, Oxford Road, Manchester M13 9PL, UK

\section{Mitchell Lyle}

Department of Oceanography, Texas A\&M University, 3146 TAMU, College Station, Texas 77843-3146, USA

\section{Jan Backman}

Department of Geology and Geochemistry, Stockholm University, Svante Arrhenius Vag 8c, S-10691 Stockholm, Sweden

\section{Heiko Pälike}

School of Ocean and Earth Science, National Oceanography Centre, University of Southampton, Southampton SO14 $3 Z H, U K$

[1] A recent expedition to the equatorial Pacific surveyed over $60,000 \mathrm{~km}^{2}$ of seafloor using swath map imaging and high-resolution seismic profiling. This survey revealed the common occurrence of large pits in the biogenic sediments that are usually associated with basement highs. The pits range in size up to a few kilometers across and are on the order of $50 \mathrm{~m}-100 \mathrm{~m}$ deep. They were found on seafloor ranging in age from $15 \mathrm{Ma}$ to $55 \mathrm{Ma}$, with overlying sediment cover up to $500 \mathrm{~m}$ thick. We link their origin with hydrothermal discharge through conduits created by differential compaction and fracturing over basement highs and by basement faulting that penetrates the overlying sediments. Although carbonate dissolution is likely to be associated with the formation of the pits, their occurrence shows no consistent relationship with the present calcite compensation depth (CCD).

Components: 7276 words, 9 figures.

Keywords: hydrothermal; equatorial Pacific; pits.

Index Terms: 3022 Marine Geology and Geophysics: Marine sediments: processes and transport; 3017 Marine Geology and Geophysics: Hydrothermal systems (0450, 1034, 3616, 4832, 8135, 8424); 3021 Marine Geology and Geophysics: Marine hydrogeology.

Received 6 October 2006; Revised 17 December 2006; Accepted 26 December 2006; Published 24 March 2007.

Moore, T. C., Jr., N. C. Mitchell, M. Lyle, J. Backman, and H. Pälike (2007), Hydrothermal pits in the biogenic sediments of the equatorial Pacific Ocean, Geochem. Geophys. Geosyst., 8, Q03015, doi:10.1029/2006GC001501. 


\section{Introduction}

[2] Recent use of swath mapping of the deepseafloor, combined with high-resolution reflection seismic profiling, has revealed the relatively common occurrence of what appear to be erosional pits in the seafloor over the equatorial Pacific mound of biogenic sediments. The pits range from a few hundred meters up to a few kilometers in horizontal dimension and appear to be on the order of $50 \mathrm{~m}$ to $100 \mathrm{~m}$ deep. These pits appear identical to the trough described by Mayer [1981] in a deeptow acoustic survey conducted in the same general region (Figure 1). They are morphologically similar to other pits formed by salt dissolution in regions of salt domes [Mayer, 1981; Ross et al., 1978; Walker and Ensminger, 1970] and by gas and liquid expulsion from sediments [Hovland et al., 2002]. They are much larger than pits and pockmarks noted by other authors in shallower waters, usually occurring in rapidly accumulating glacial-marine silts and clays and attributed to pore water expulsion [e.g., Harrington, 1985, and references therein].

[3] The sediments of the equatorial Pacific are largely biogenic, but drilling in this region over the past 35 years has never encountered large excess pore pressures or any significant gas accumulation. Nor are the sediments of the equatorial mound particularly rich in organic carbon. Mayer [1981] associated the pit with tensional fractures over basement highs (Figure 2) and relied primarily on physical erosion combined with the dissolution of carbonate to explain the loss of material that was removed from the pit. However, he presented no strong evidence for current velocities capable of such erosion even though current meters had been deployed in the area and in the elongate pit itself. This worried Mayer [1981] and he presented other hypotheses that seemed even less satisfactory. He also wondered why similar features were not more commonly found.

[4] A few such features have since been documented in the region. In the survey areas for Sites drilled on DSDP Leg 85 in the equatorial Pacific, Shipley et al. [1985] discuss and illustrate erosional channels that were mapped at Site $574\left(4^{\circ} 13^{\prime} \mathrm{N}\right.$, $\left.133^{\circ} 20^{\prime} \mathrm{W}\right)$ and Site $575\left(5^{\circ} 51^{\prime} \mathrm{N} 135^{\circ} 02^{\prime} \mathrm{W}\right)$. In their Seabeam map of the Site 574 area they show a few small areas of closed bathymetric contours (20-40 m deep), at least one of which appears to occur over a basement ridge [Shipley et al., 1985, Figures 7 and 9]. An erosional channel at Site 575 shows well over $200 \mathrm{~m}$ of relief and is probably associated with turbulent flow around a nearby seamount. More recently, Bekins et al. [2006] have identified two such erosional pits in the eastern equatorial Pacific near ODP Sites 1225 and 1226.

[5] At about the same time that Mayer [1981] described the pit (or trough) in the equatorial Pacific sediments, other studies had revealed the presence of negative heat flow anomalies in regions of older seafloor [Sclater et al., 1976; Anderson et al., 1979]. The data presented by Sclater et al. [1976] and Anderson et al. [1979] led to speculation regarding the possible role of heat advection in waters that flowed in the upper few hundred meters of fractured ocean crust. In these and other studies of hydrothermal circulation in the deep sea, the ocean crust acts as the aquifer and sediment cover acts as the aquatard. A sharp contrast in the relatively high permeability of the upper crustal rocks compared to that of the sediments, combined with a substantial relief in the basement topography, can set up pressure gradients in the permeable crust, with thermal gradients in the subseafloor enhanced by horizontal flow of waters [Davis and Becker, 2004; Fisher, 2004; Spinelli et al., 2004; and references therein]. What is required for such active flow is an area where the crust is exposed and can be recharged with seawater and an area where the heated waters discharge [Anderson et al., 1979; Baker et al., 1991; Fisher et al., 2003a, 2003b; Bekins et al., 2006].

[6] Sclater et al. [1976] suggested that once sediment thickness was greater than about $200 \mathrm{~m}$, heat flow anomalies became small, there was no loss of heat to seawater by mass transport, and the estimates of average ocean heat flow were more reliable. However, the "reliable" average heat flow data for the region of the equatorial Pacific sediment mound, where sediments are on the order of $400 \mathrm{~m}$ thick (Figure 1), is substantially below that predicted by theoretical models of heat flow [Sclater et al., 1976, Figure 7a]. More recent studies indicate that heat flow from the ocean crust only approach a theoretical conductive value on crust older than $\sim 50-65$ Ma [Stein and Stein, 1992], although there is some heat flow evidence for continued hydrothermal flow and associated heat loss in much older crust [Von Herzen, 2004]. The occurrence of these heat flow anomalies in the older sedimented crust suggest that this is an important and pervasive process that could have broad implications regarding chemical, as well as heat, exchange between the upper crust and the 


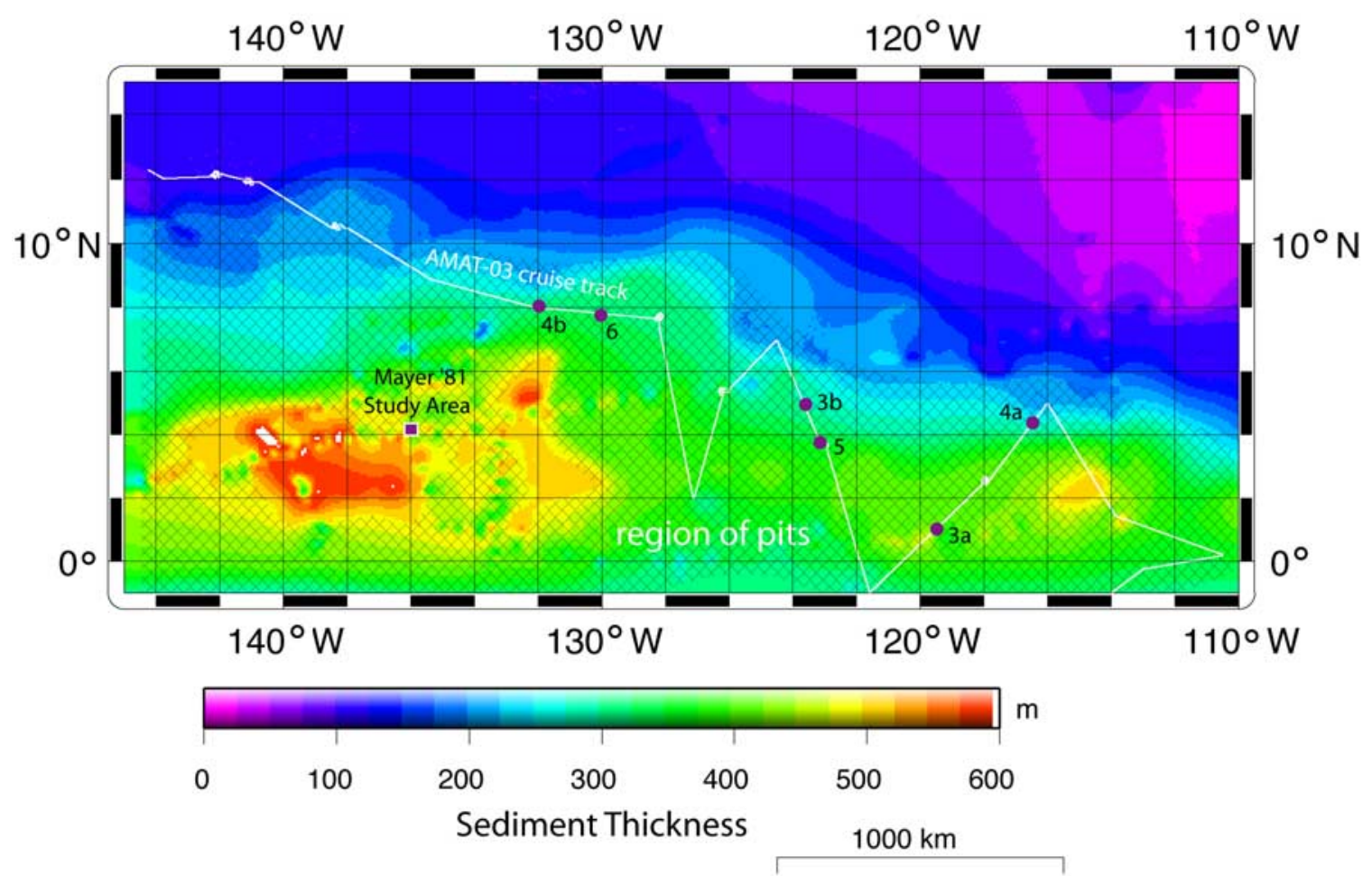

Figure 1. Cruise track of AMAT03 in the tropical Pacific on a map of sediment thickness in the equatorial Pacific sediment mound (in part from D. L. Divins, NGDC Total Sediment Thickness of the World's Oceans and Marginal Seas, http:/www.ngdc.noaa.gov/mgg/sedthick/sedthick.html) [see also Mitchell, 1998]. The study area location of Mayer [1981] is indicated by a solid square. The locations of Figures 3-6 are indicated by solid circles. Crosshatched area indicates region in which it is estimated that pits discussed in this paper could be found.

oceans, even in regions distant from the crustal spreading centers [Wheat and Mottl, 2004; Kastner and Rudnicki, 2004; Bickle and Elderfield, 2004].

[7] To establish patterns of anomalies in the crustal heat flow requires closely spaced measurements of heat flow in relatively small areas. In one of the first such detailed studies of heat flow in ridge flank areas with crustal ages ranging up to $55 \mathrm{Ma}$, Anderson et al. [1979] give evidence of convection "cells" within and beneath red clay sediments (10 $\mathrm{m}-\geq 100 \mathrm{~m}$ thick) in the Crozet Basin of the Indian Ocean. They estimated the lateral dimensions of these cells to be 5 to $10 \mathrm{~km}$ and the upward convection through the clays to take place at a rate slightly less than $1 \mathrm{~m} / \mathrm{yr}$.

[8] The lateral dimensions of the convection cells envisioned in most modeling efforts describing hydrothermal circulation in sedimented crust generally range up to about $10 \mathrm{~km}$ [Fisher, 2004, and references therein]; however, Baker et al. [1991] felt that the separation of discharge and recharge areas of less than $20 \mathrm{~km}$ was inconsistent with the existing geophysical data for the equatorial Pacific region. Given the many unknown aspects of offflank circulation systems, Fisher [2004] questions whether the aspect ratio of the circulation cells as modeled (usually $\sim 1: 1$ ) is actually favored by natural systems.

[9] The idea that hydrothermally driven flow of waters in the upper oceanic crust was the cause of the observed heat flow anomalies was strongly supported by a careful examination of the geochemistry of pore waters in sediments overlying regions of older crust in the tropical Pacific [e.g., Baker et al., 1991; Oyun et al., 1995; Kastner and Rudnicki, 2004]. Profiles of calcium, magnesium, strontium and sulfate ions, as well as strontium isotopes in sedimentary pore waters from this region showed a pattern of increasing and decreasing values that clearly indicated diffusion from the basement into the lower part of the sediment column. The results of this diffusion were that pore waters near the base of the sediment column had chemical compositions very similar to that of the ocean bottom waters in the region. In combination 

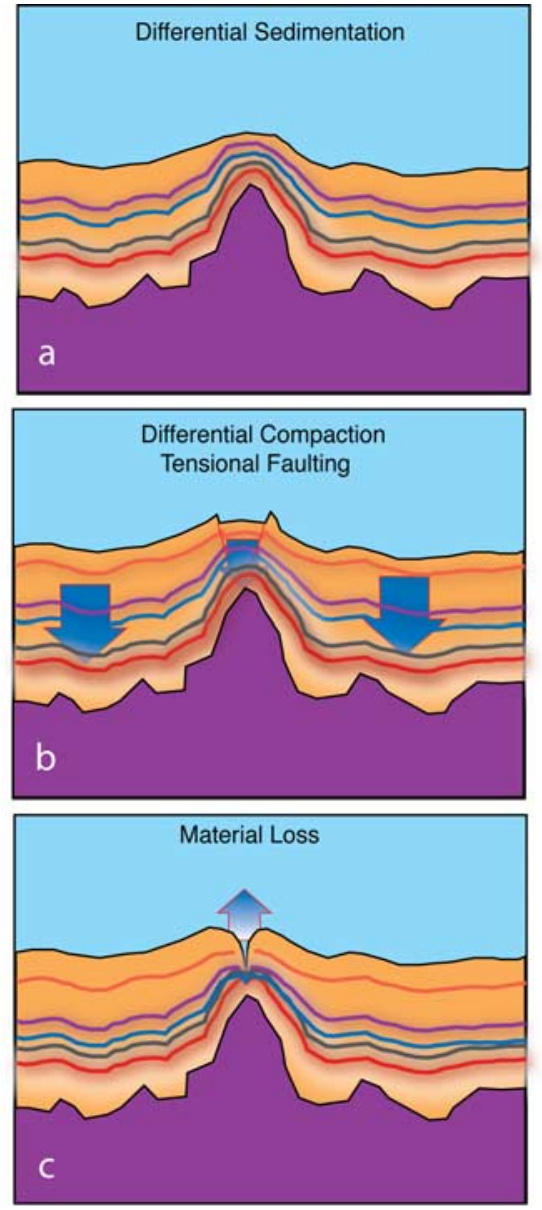
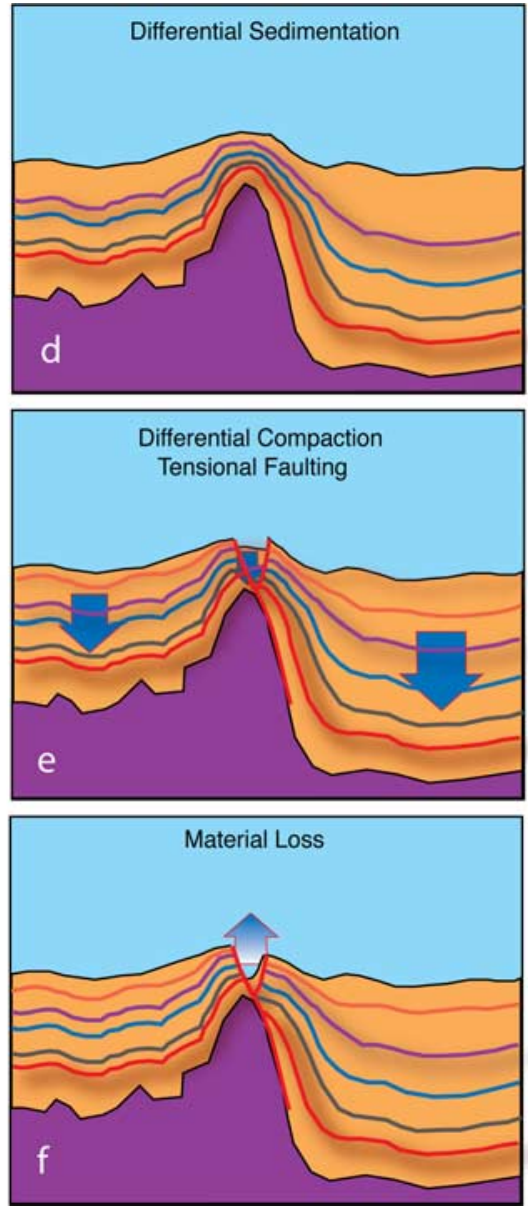

Figure 2. Cartoons illustrating the proposed development of tensional fracturing and the development of pits over basement highs (a-c) where flanking basins have approximately the same thickness of fill and (d-f) where the basin fill is asymmetrical. After Mayer [1981].

with the data on heat flow anomalies, the clear explanation for these observations was that bottom waters entered the upper crust in regions of crustal exposure (e.g., seamounts, fracture zones) and flowed laterally in the upper crust while diffusing into the lower sediment column which served as a less-than-perfect seal [Baker et al., 1991].

[10] What remained was a more detailed explanation of exactly how and where the bottom waters entered and exited the system and what impact these waters had on the crustal rocks and the overlying sediments. In more recent times, interest has grown in the role these waters play in sub seafloor microbial ecology [e.g., D'Hondt et al., 2003; Staudigel and Furnes, 2004; and references therein]. Data from the central tropical Pacific was used by Baker et al. [1991] to show that the crustal outcrops forming a necessary part of the proposed hydrothermal system occurred at least every
200 km. Baker et al. [1991] also explored models based on available data that would give some indication of the distance and rates at which these hydrothermal waters might travel. In general, their results indicated that the waters would have residence times less than 30,000 years and probably on the order of 10,000 years, consistent with the relatively small chemical change in the pore waters at the base of sedimentary sections relative to ocean bottom waters. Flow rates through the sedimented older crust are generally estimated to range from about 1 to $20 \mathrm{~m} / \mathrm{yr}$ [Anderson et al., 1979; Baker et al., 1991; Elderfield et al., 1999; Fisher and Becker, 2000; Bekins et al., 2006].

[11] Bekins et al. [2006] have taken these studies a step further. On the basis of heat flow and pore water data, they have linked the depressions found near ODP Sites 1225 and 1226 with the hydrothermal circulation in the surrounding areas and further 
proposed that it is the chemical dissolution of the biogenic sediments (particularly carbonate) by the hydrothermal outflow that accounts for the erosional nature of such pits as first described by Mayer [1981].

[12] As the greater swath widths of modern multibeam sonars provide much greater coverage, we have now been able to carry out a more systematic and extensive census of these features. On the basis of the work of Bekins et al. [2006] and Mayer [1981] we propose that these pits are likely to be the product of extensive hydrothermal circulation in the basement rocks and sediments. We have identified numerous examples of what appear to be focused discharge vents (pits) scattered over the Pacific equatorial mound of sediments in regions of the ocean crust ranging in age between about 15 and $55 \mathrm{Ma}$.

\section{Methods}

[13] Measurements that are discussed in this paper were made on Cruise AMAT-03 aboard the R/V Roger Revelle (Figure 1). Multibeam data were acquired with a $12-\mathrm{kHz}$ hull-mounted Simrad EM120 system [Hammerstad et al., 1991] using standard procedures. A calibration "patch test" was carried out soon after leaving port and data were corrected for water column refraction using velocity profiles computed from temperature profiles acquired using expendable bathythermographs. The sounding data were manually processed using "MB-System" software [Caress and Chayes, 1996] and gridded and displayed using "GMT" software [Wessel and Smith, 1991]. The resulting maps have a horizontal resolution of around $100 \mathrm{~m}$ near the center of the swath, limited by the filtering required to reduce effects of acoustic noise from other hull-mounted sonars. Toward the outer edges of swaths, resolution is limited by water column multiple energy and other problems, illustrated by the ragged or "noisy" appearance of the outer data (e.g., Figure 3a). Thus interpretation here concentrates on the inner $10 \mathrm{~km}$ or so of data.

[14] Two data acquisition modes were used for the seismic reflection surveys on the AMAT-03 expedition. Both the underway and IODP site survey modes used two GI airguns configured to use a 45 cubic inch $(737 \mathrm{cc})$ generator pulse followed by a 105 cubic inch $(1721 \mathrm{cc})$ injector pulse. However, the underway survey was conducted at 10 knots using the Scripps 4-channel streamer for data collection (50-m channel spacing), while the IODP site survey was carried out at 6 knots and used a 48-channel Geometrics Geo-Eel streamer (12.5 m channel spacing). Underway surveys (Figure 1) were taken between drill sites proposed for IODP Leg 314 from near ODP Site 849 $\left(0^{\circ} 11^{\prime} \mathrm{N}, 110^{\circ} 31^{\prime} \mathrm{W}\right)$ to near the end of the cruise $\left(14^{\circ} 46^{\prime} \mathrm{N}, 148^{\circ} 15^{\prime} \mathrm{W}\right)$. IODP surveys were carried out in grids around the proposed drill sites.

[15] Data from both acquisition modes were processed in a similar manner using ProMax software. Shot data were corrected for NMO moveout and stacked into common midpoint gathers. Generally, the underway data has a maximum fold of 2 while the 48-channel stacks are 10-fold. The data were then band-pass filtered using a zero-phase Butterworth filter between 30 and $250 \mathrm{~Hz}$, and migrated assuming a $1500 \mathrm{~m} / \mathrm{sec}$ water velocity and using a Stolt iterative migration algorithm.

[16] Of the data shown in this paper, Figures 3a, $3 \mathrm{~b}, 4 \mathrm{a}$, and 6 were acquired in the underway acquisition mode, while Figures $4 \mathrm{~b}$ and 5 were acquired in the IODP site survey mode.

[17] Pits and basement outcrops were counted in the swath transect and in individual surveys of potential drill sites. Their character was verified when these features were crossed by seismic lines. The surveys were formed by overlapping swath images of the seafloor over an area of about $1000 \mathrm{~km}^{2}$. The total pit count excludes what appear to be multiple overlapping pits and apparent pits that are near the resolution of the swath system. When comparing pit and basement outcrop abundance to water depth, basement relief, and sediment thickness we have normalized pit and outcrop occurrence by percent of the data sampled at different water depths, different basement relief, and different sediment thicknesses (measured over $<20 \mathrm{~km}$ distances). We suggest that the resulting estimates of pit abundance are conservative. Outcrop identification and abundance estimates are a bit more subjective. No effort was made to scale the size of an outcrop; thus each seamount, fracture zone, exposed flank of a basement ridge, and isolated basement high, count as "one unit of outcrop" when they are encountered in the data. Often it is difficult to exclude the possibility that a few meters of sediment may cover parts of a basement outcrop, especially where slopes are relatively steep. We feel these data are more detailed than those used by Baker et al. [1991] and provide an appropriate comparison to the 

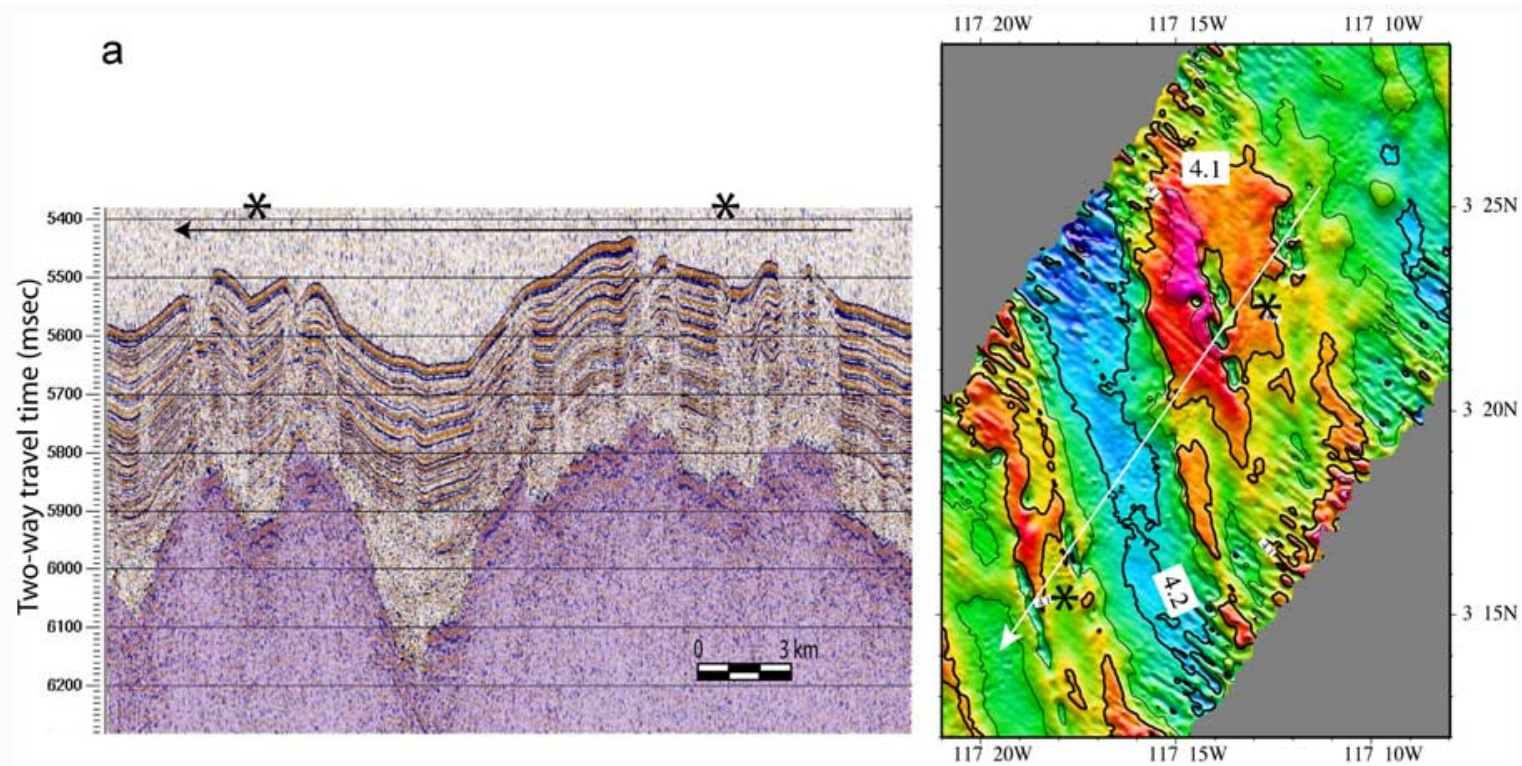

b
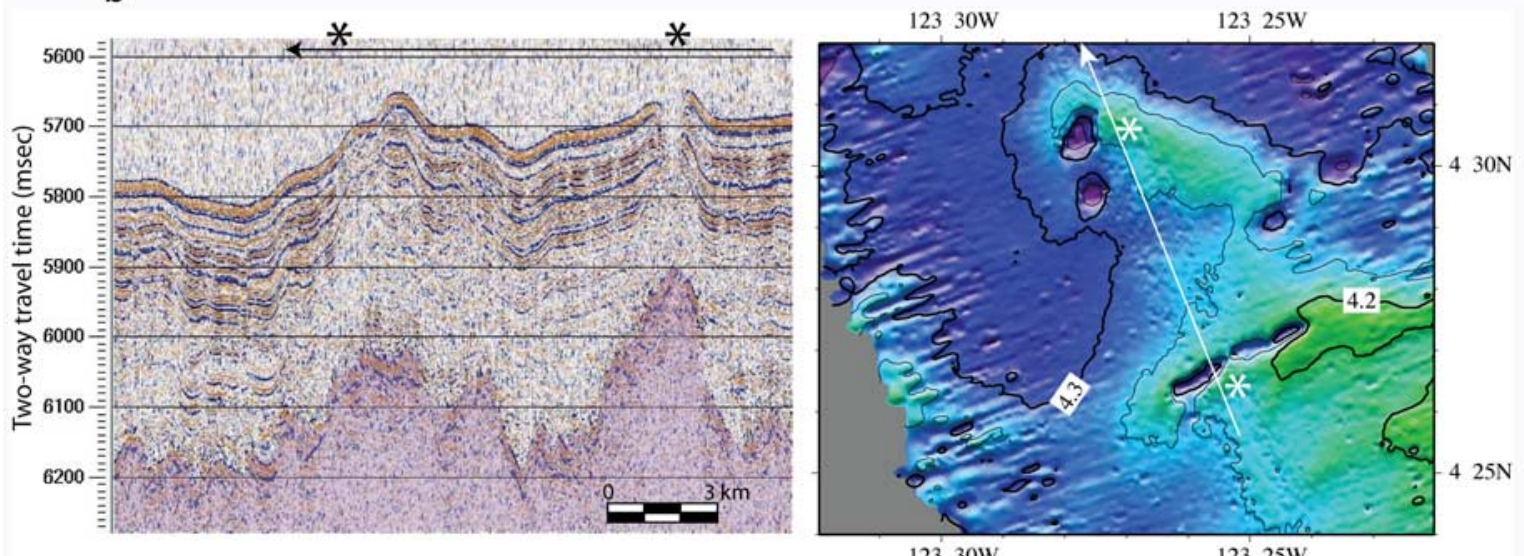

$12330 \mathrm{~W}$

$12325 \mathrm{~W}$

Figure 3. (a) A series of four pits imaged in both (left) the seismic line and (right) the swath map (compare to Figures $2 \mathrm{a}-2 \mathrm{c}$ ). (b) (left) A very elongate pit crossed by the seismic line and (right) several subcircular pits seen in the swath map but not imaged by the seismic line. Note the discontinuous nature of seismic reflections in the region where pits occur nearby. Acoustic basement is shaded in both Figures $3 \mathrm{a}$ and $3 \mathrm{~b}$. Seismic depths in milliseconds; contours in $\mathrm{km}$.

estimate of pit abundance taken from the same data set.

\section{Results}

[18] The common feature that first drew our attention to these pits was their occurrence in the seismic record over basement highs (Figures $2 \mathrm{a}-$ $2 \mathrm{c}$ and 3). A plausible explanation for this association comes from Mayer [1981] in which he postulates that the effects of differential sedimentation over a basement high and in adjacent basins leads to differential compaction and ultimately to the development of a tensile stress field over the high. For the region covered by the AMAT-03 Cruise (Figure 1) the sedimentary section over the ridges (measured on ridges not having pits) was on average about $70 \%$ of the thickness in adjacent basins. With compaction, the resulting stresses over the highs would give rise to normal faulting and slumping (Figures $2 \mathrm{a}-2 \mathrm{c}$ ). If the basins on either side of the basement high are asymmetrical then the side with the greater thickness of sediment will compact more, resulting in an asymmetrical stress field and a greater chance of slumping and failure on that side of the high (Figures $2 \mathrm{~d}$ and 2e). With such failure the crest of the basement high will lie near the foot of the 

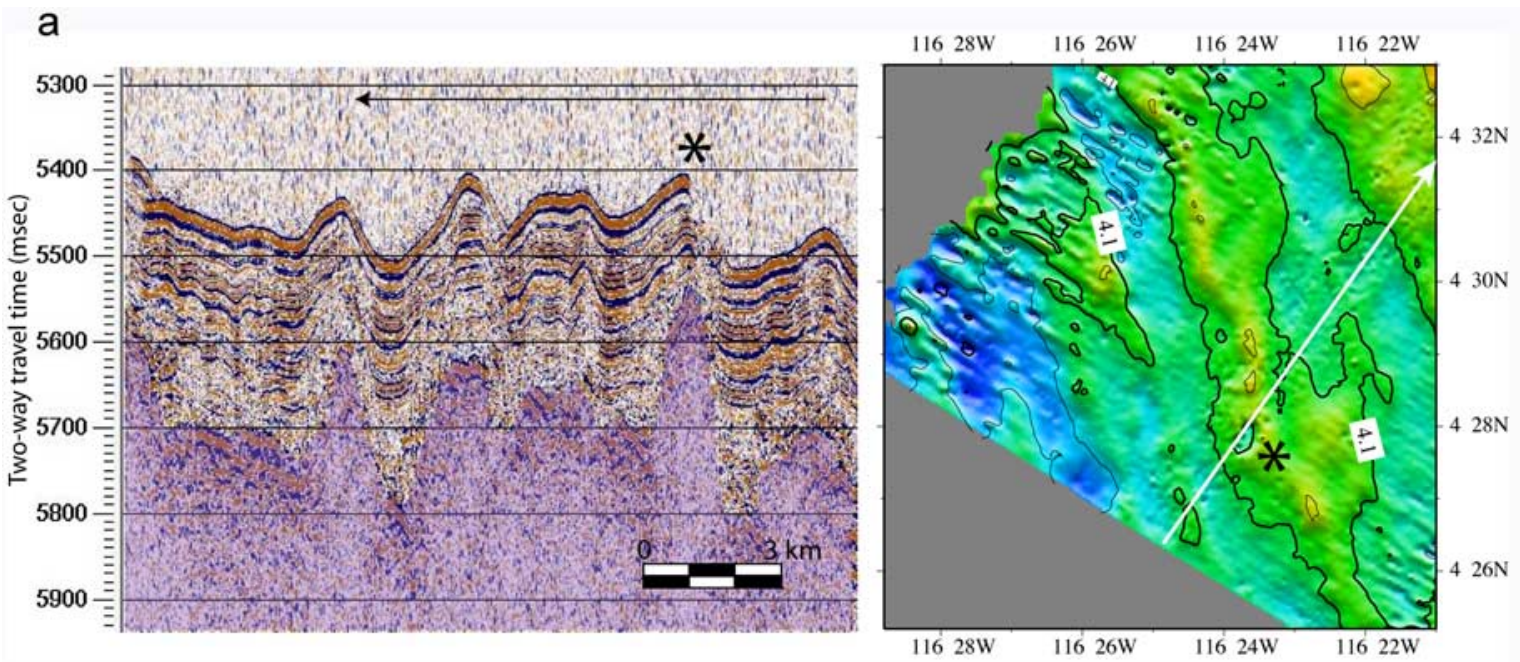

b
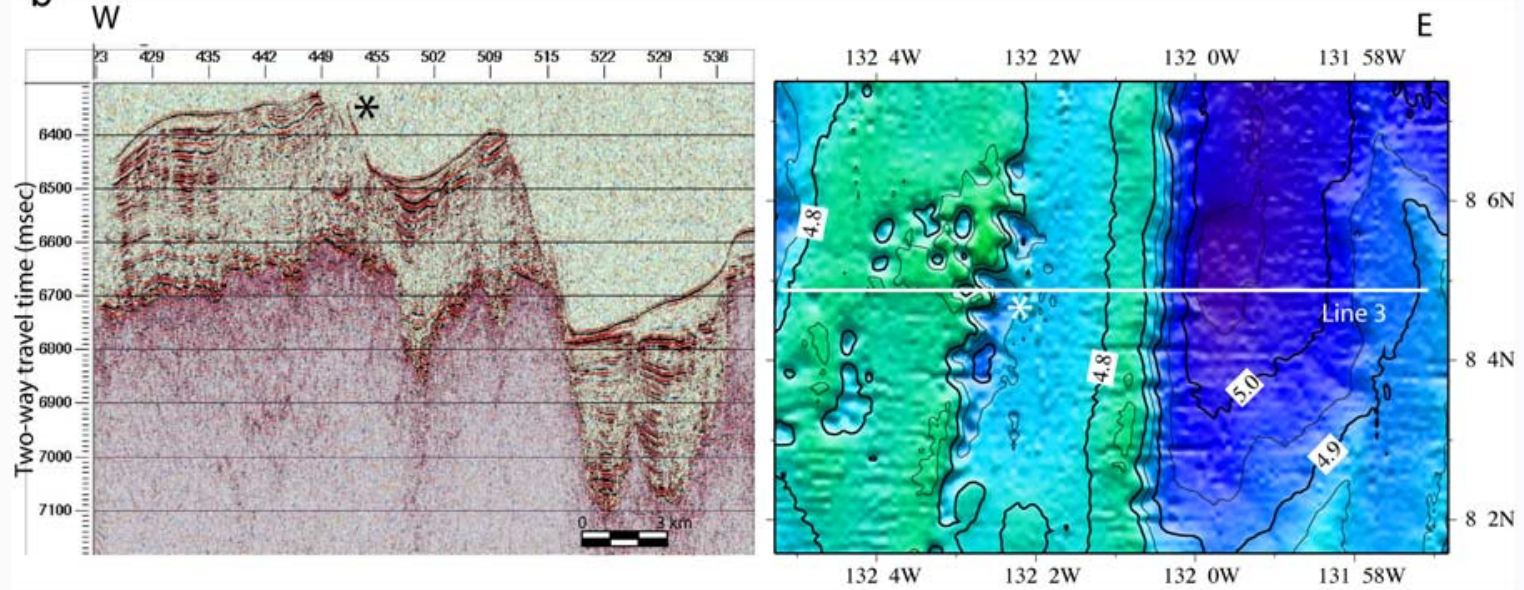

Figure 4. (a) A single pit (marked by an asterisk in both the swath map and the seismic line) located over the flank of a basement high adjacent to the deeper basin (compare to Figures 2d-2f). (b) Two scarps flanking the west side of a basin in the detailed survey area PEAT 4 . The eastern scarp is relatively straight with a basement high exposed at its base. The basement high associated with the western scarp lies beneath the base of the scarp, which is formed by a series of overlapping pits (shown in swath map on right). Note the field of pits located to the west of the western scarp in the swath map (right); in the seismic line (left), note the buried pit in the central basin lying over a relatively sharp ridge within the basin. Acoustic basement is shaded in both Figures 4a and 4b. Seismic depths in milliseconds; contours in $\mathrm{km}$.

bathymetric scarp; and in some cases, the basement may actually be exposed (Figure 4b). In our survey of the equatorial Pacific we identified pits that occurred directly over basement highs (Figures 3 and 5) as well as pits that occurred at the base of bathymetric scarps (Figures $4 \mathrm{a}$ and $4 \mathrm{~b}$ ).

[19] The shape of the pits varied from subcircular to elongate (e.g., Figure 3b). The subcircular pits in Figure $3 \mathrm{~b}$ are about $1 \mathrm{~km}$ wide, whereas the elongate pit is about $4 \mathrm{~km}$ long and less than $1 \mathrm{~km}$ wide. This is comparable to the elongate pit mapped by Mayer [1981], which was $6 \mathrm{~km}$ long and about $2 \mathrm{~km}$ wide. However, the trough mapped by Mayer [1981] may have been formed by coalescing pits that were not resolved in the survey. The true shape of these pits is better revealed in the swath maps (Figures $4 \mathrm{~b}$ and 5) made in the detailed survey areas. They provide a clearer image of the features surrounding the seismic lines. Two seismic lines cross within a field of pits (Figure 5) some $17 \mathrm{~km}$ wide. The pits trend to the NNE with seismic line 6 crossing at a higher angle to this trend than line 9. From the swath map we can see that seismic line 9 passes through three closely spaced pits, which on the seismic line itself looks 


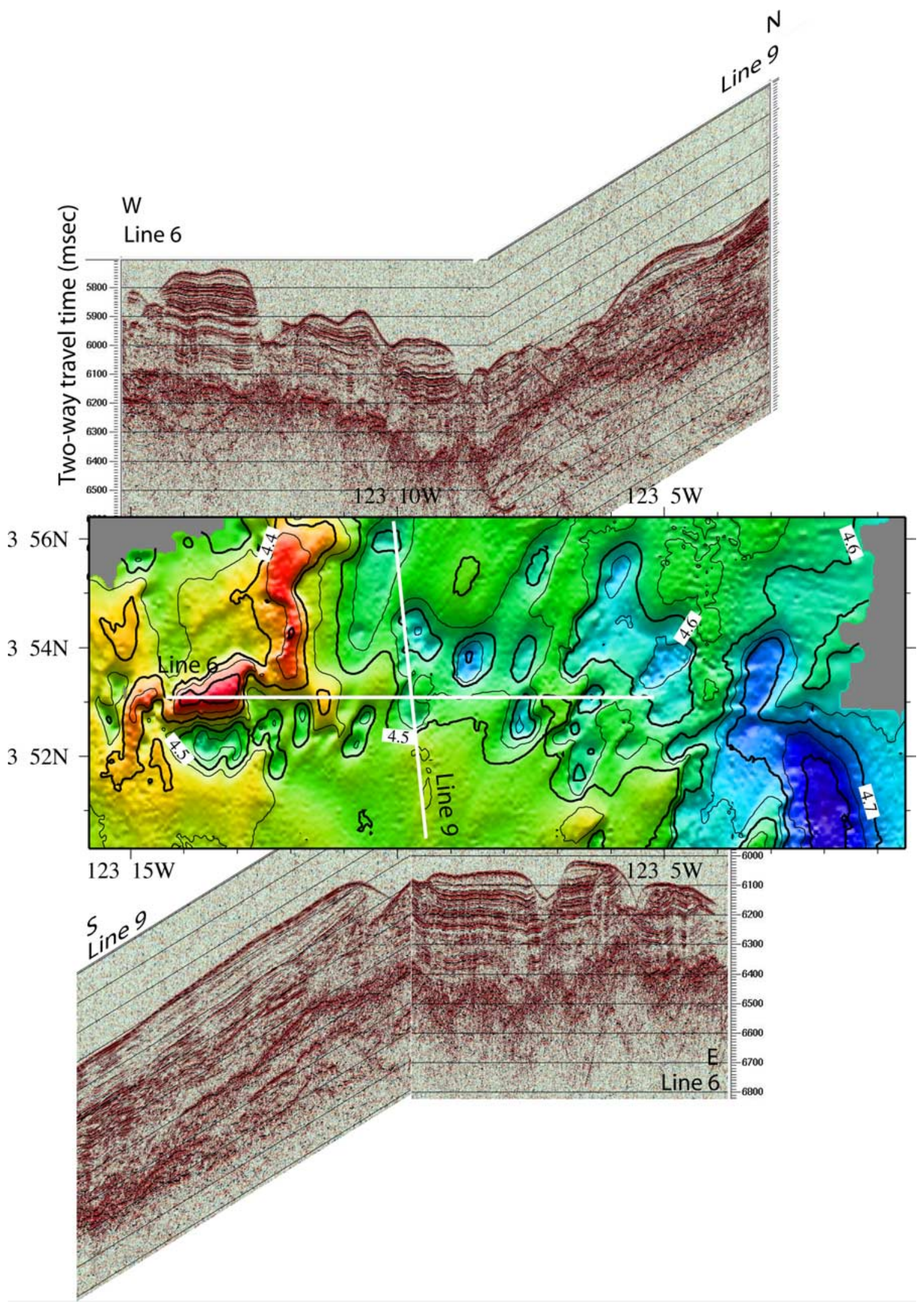

Figure 5 

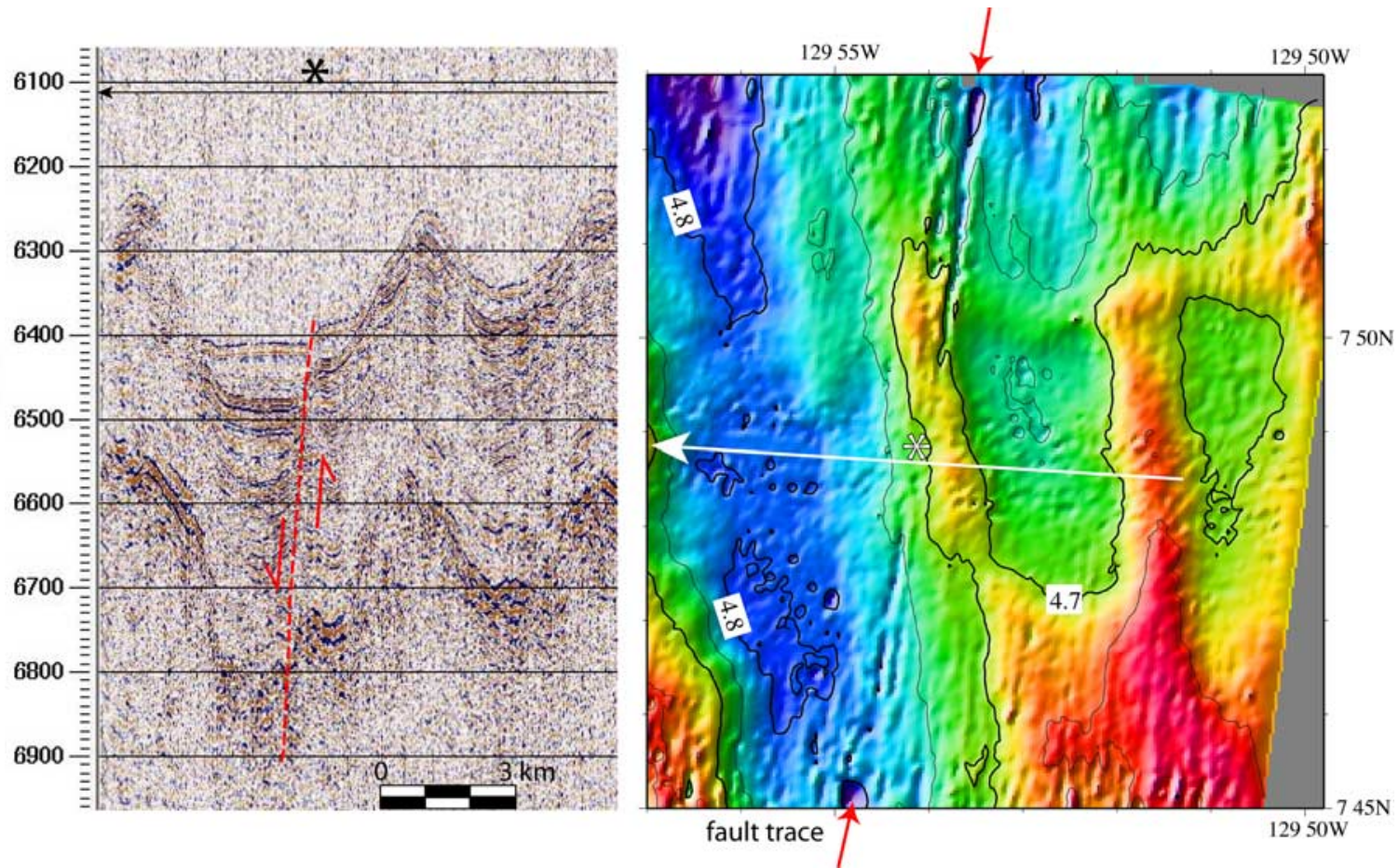

Figure 6. A series of pits lying along a linear NNE trend (right), which appears to follow a fault trace seen in the seismic line (left) that crosses this trend. Note that the pits tend to be larger in the basin areas and are not imaged in the seismic line itself. Seismic depths in milliseconds; contours in $\mathrm{km}$.

like one irregular pit some $8 \mathrm{~km}$ long; whereas the pits crossed on Line 6 appear as narrower, more discrete features. Note also that the small hill on the western side of the swath image is not located over a basement high; rather it is an erosional remnant surrounded by pits.

[20] The "low-altitude" deep-tow crossings of the Mayer [1981] pit and photographs of the pit itself have given us valuable insights into its characteristics. Slopes on one side of the pit wall were sometimes greater than $60^{\circ}$ between intervening terraces, and the $4-\mathrm{kHz}$ profiles show clear indications of normal faulting. Small normal faults could also be detected in and near the pit. The terraces and the pit bottom appeared to be free of loose, redeposited sediments. The terraces were often covered with manganese nodules (not found elsewhere in the surveyed area). These characteristics are indicative of nondeposition and erosion.
[21] The seismic images of the pits almost always show disruptions of the otherwise coherent reflections between the base of the pit and the basement high (Figures 3, 4, and 5). This may be an artifact of the reflection geometries involved; however, these seismic "voids" were pointed to by Harrington [1985] as suggestive of mechanical disturbance of the layers beneath the pits. Harrington [1985] postulated the loss of pore water from under compacted glacial-marine clays as the cause of this disruption and contrasted it to acoustic "masking" associated with gas in the pore waters. These acoustic voids are seen on the northern end of the seismic line in Figure 3b, even though the pits that lie near this line are not imaged.

[22] In Figure 4a there is a single, 1-km pit lying on the deep basin side of a basement high. The basement high itself is not exposed; however, the acoustic void over the high extends up to the base

Figure 5. A field of pits is imaged in the detailed survey area PEAT 7. Two seismic lines that cross in the middle of this area are shown above and below the segment of the swath map. The northern and southern parts of line 9 are angled and joined to the eastern and western parts of Line 6 at their crossing. Note that the hill at the western end of line 6 is an erosional remnant surrounded by pits. Note also that the northern half of line 9 crosses several coalescing pits. Seismic depths in milliseconds; contours in $\mathrm{km}$. 


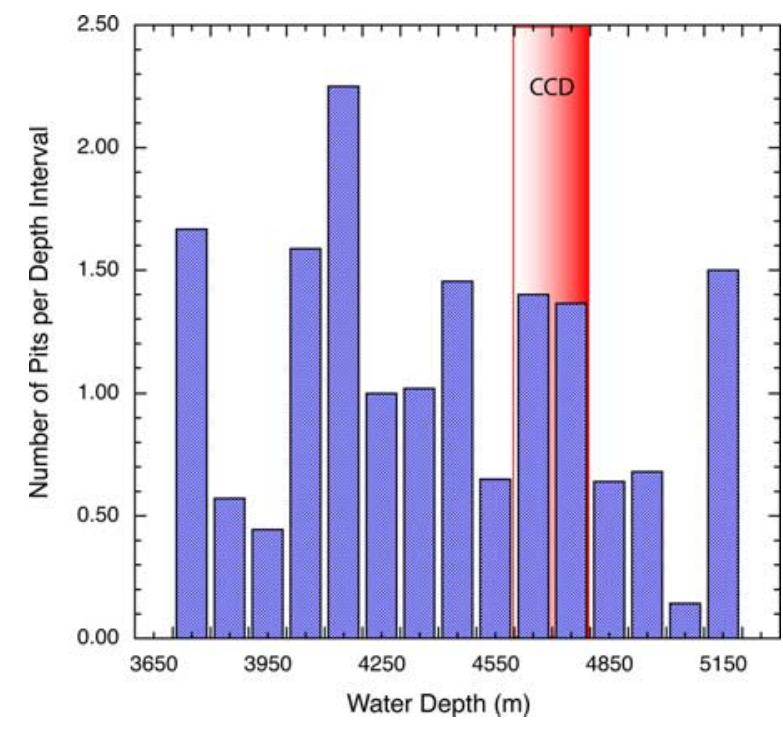

Figure 7. Occurrence of pits as a function of water depth, normalized by dividing the number of pits occurring within each $100 \mathrm{~m}$ water depth interval by the number of times each interval was sampled (measured over $20 \mathrm{~km}$ increments) in the transect (Figure 1). The approximate depth of the Calcite Compensation Depth (CCD) in the equatorial Pacific is shown by a shaded vertical bar. The modern CCD varies from $\sim 4800 \mathrm{~m}$ within $4^{\circ}$ of the equator to $\sim 4600 \mathrm{~m}$ north of $4^{\circ} \mathrm{N}$ in the tropical Pacific [Van Andel and Moore, 1974]. During the Neogene the CCD in this region varied from $\sim 4000 \mathrm{~m}$ to $\sim 4900 \mathrm{~m}$. There does not appear to be a strong relationship between water depth and pit occurrence.

of a bathymetric scarp that offsets reflections by about $100 \mathrm{msec}(\sim 75 \mathrm{~m})$. This could be the early phase of scarp development that is much more fully evolved in Figure 4b, located some $1500 \mathrm{~km}$ to the west (Figure 1). The swath image in Figure $4 \mathrm{~b}$ is also taken from a survey area. It shows a fairly sharp and linear scarp coming up from the basin (at time $05: 15 \mathrm{hrs}$ on the seismic line 3), with the basement high exposed where the line crosses the scarp. To the west the line crosses a second scarp; however, this scarp is highly irregular and pitted, with a whole field of pits located westward of the scarp. Also seen in seismic line of Figure $4 b$ is an uppermost, acoustically transparent layer that thickens into the eastern side of the basin and on the western-most side of the western plateau. This layer appears to be made up of redeposited sediment transported toward the west. Within the deep basin these sediments completely cover a small pit located over a very sharp ridge in the center of the basin (at hour 05:26 on the seismic line). This is one of only two or three examples that we found in the AMAT-03 seismic data where a pit had been covered by sediment and appeared to be no longer active.

[23] A very different pit association is seen in Figure 6 in which a linear trend of relatively small pits appear to be associated with a normal fault that lies somewhat off the perpendicular to the ship's track and at an acute angle to the topography. The fault crosses the ship's track at the eastern edge of a basin and shows clear offsets in all but the uppermost seismic layer. This layer shows differential sedimentation across the bench created by the fault. No pit is seen on the seismic line but extending north and south of the line a series of pits is seen, with the largest pits found in the deeper parts of the basins.

[24] Bekins et al. [2006] argue that dissolution of carbonate is enhanced by hydrothermal flow, and this together with turbulent bottom water flow and slumping and faulting [Mayer, 1981] give rise to pit formation. Over 300 similar pits were identified in our survey. In Figure 7 we show normalized pit occurrence (number of pits identified in each water depth interval divided by number of times each $100 \mathrm{~m}$ depth interval was sampled), plotted as a function of water depth. There does not appear to be any consistent relationship between pit abundance and water depth even though the depths sampled span the modern CCD in the Pacific. However, the geothermal heating and subsequent cooling of hydrothermal waters passing through the upper crust should lead first to precipitation of carbonate, and then with cooling, to an under saturation of the waters with respect to carbonate and strong dissolution of the carbonate sediments through which they pass [Bekins et al., 2006]. If this is the case no relationship between water depth and pit occurrence should be expected.

[25] There does not appear to be any relationship between pit abundance and age of the ocean crust, latitude, or longitude. There is a slight tendency for the pits to be more abundant in areas with higher basement relief. Pits do occur over a certain range of sediment thickness. They were not found where sediment in valleys adjacent to the pits was thinner than about $150 \mathrm{~m}$ or thicker than about $500 \mathrm{~m}$ (Figure 8). The pits identified by Mayer [1981] and by Shipley et al. [1985] are in areas with sediment cover of about $500 \mathrm{~m}$. Those identified by Bekins et al. [2006] are in areas with sediment cover of about $300 \mathrm{~m}$. In our study pits are most frequently found in regions with sediment cover of 300$350 \mathrm{~m}$ in the adjacent valleys (Figure 8). 


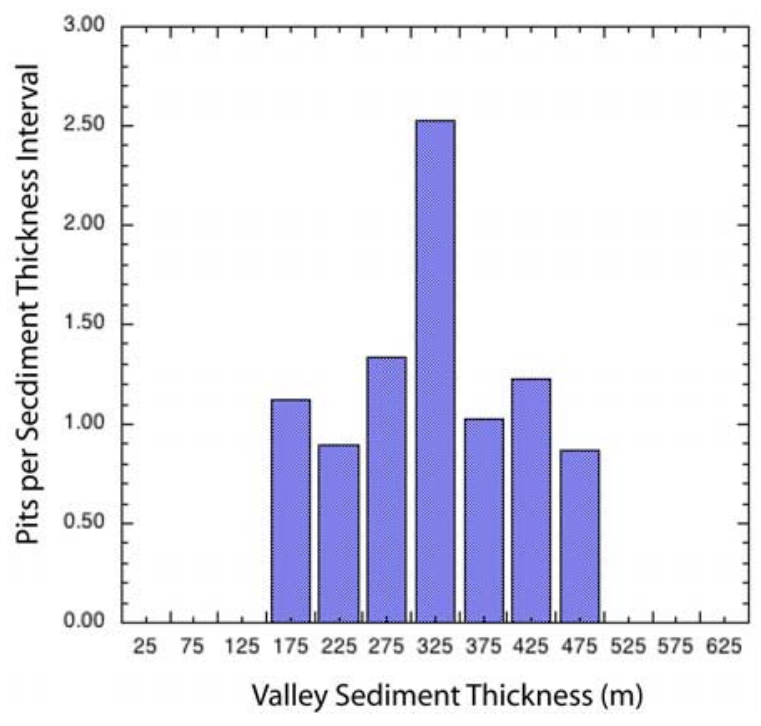

Figure 8. Occurrence of pits as a function sediment fill in adjacent valleys, normalized by the number of times each interval of valley fill was sampled (measured over $20 \mathrm{~km}$ increments) in the transect (Figure 1). Thickness estimates are based on seismic traveltime assuming a sediment sound velocity of $1500 \mathrm{~m} / \mathrm{sec}$. Data were binned in $50 \mathrm{~m}$ thickness intervals. Pits were not found when valley fill was less than about $150 \mathrm{~m}$ or greater than about $500 \mathrm{~m}$. Pits occurred most frequently where basin sediment thickness was between $300 \mathrm{~m}$ and $350 \mathrm{~m}$

[26] The cross-hatched area in Figure 1 shows the region of the tropical Pacific where sediment thickness ranges over these values, and where presumably such pits can be found. The Mayer [1981] study area lies just within this region. Assuming an average width of the swath mapped in transit (Figure 1) of $10 \mathrm{~km}$, and a total area of $8000 \mathrm{~km}^{2}$ for the eight detailed survey areas, the average pit density for the region is about 1 per $230 \mathrm{~km}^{2}$. If we exclude areas with sediment cover less than $150 \mathrm{~m}$ (Figure 1), average pit density in the remaining area is 1 per $210 \mathrm{~km}^{2}$. As seen in the figures (e.g., Figures $4 \mathrm{~b}$ and 5) the pits are frequently clustered and overlapping and are probably not randomly distributed; thus this is a very rough estimate of the frequency of pit occurrence in the region.

[27] Not unexpectedly, outcrop abundance also varies with maximum sediment thickness in the valleys (Figure 9), with pits being generally more abundant than outcrops by a factors of 2 to 5. Only where the sediment cover becomes relatively thin $(\leq 150-200 \mathrm{~m})$ are outcrops more abundant than pits. Averaged over the entire area where pits are found, outcrop density is about 1 per $630 \mathrm{~km}^{2}$, about a third of the average pit density.

\section{Discussion and Conclusions}

[28] We have identified numerous examples of the type of pit first mapped and discussed by Mayer [1981]. Bekins et al. [2006] give two other examples and a careful evaluation of how such pits could be formed. The mystery of why numerous examples of such pits have not been identified before probably lies in the fact that only recently have transits and surveys of the equatorial sediment mound area included both high-resolution seismic data and high quality swath mapping. It takes both views of these features to convince one's self that they generally follow a pattern of occurrence that fits the Mayer [1981] hypothesis concerning the relationship between the tensile stress development over basement highs and pit development.

[29] Mayer [1981] pointed to faulting and slumping, as well as dissolution of carbonate enhanced by turbulent flow over the sharp topographic irregularity of the trough and its associated ridges and scarps to help explain the trough formation. These two factors may indeed play an important role in

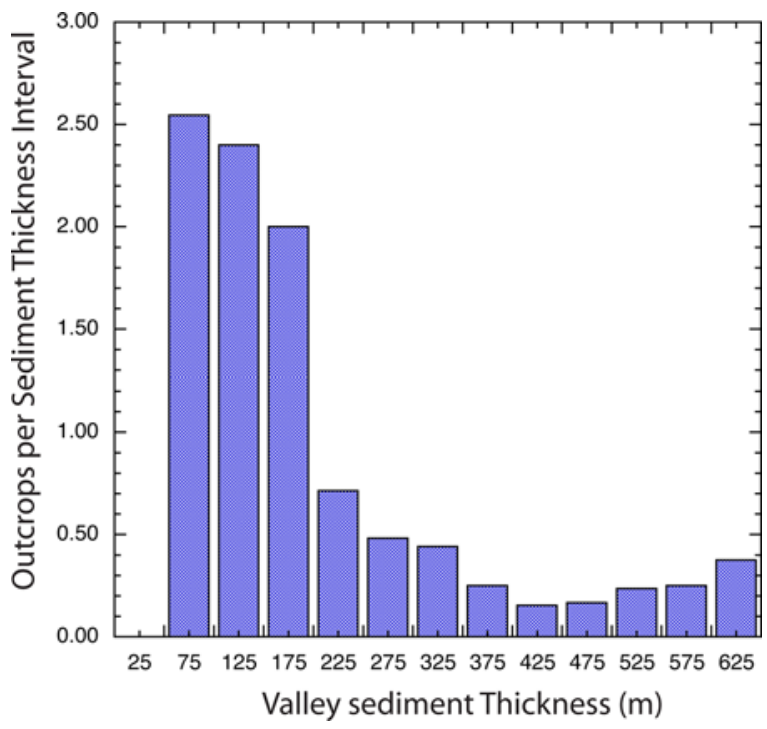

Figure 9. Occurrence of basement outcrops (including seamounts, fracture zones, isolated basement highs, and exposed flanks of basement ridges) as a function sediment fill in adjacent valleys, normalized by the number of times each interval of valley fill was sampled (measured over $20 \mathrm{~km}$ increments) in the transect (Figure 1). Thickness estimates are based on seismic traveltime assuming a sediment sound velocity of $1500 \mathrm{~m} / \mathrm{sec}$. Data were binned in $50 \mathrm{~m}$ thickness intervals. 
pit formation. Our data suggest another possible mechanism that was not seriously considered 25 years ago: hydrothermal flow and expulsion along vertical zones of high permeability. The fractures and faults associated with the tensile stresses proposed by Mayer [1981] could provide the conduit for fluid passage through the sediment blanket overlying the relatively warm upper ocean crust. The seismic "voids" seen beneath the pits give evidence of the disruption caused by episodic fluid passage, much as that seen in areas where pore water expulsion has occurred [Harrington, 1985]. The work of Bekins et al. [2006] show how heat flow measurements and the geochemistry of pore waters in drill cores located near pit-like depressions in the seafloor support the idea that hydrothermal flow and dissolution of biogenic sediments can lead to the development and maintenance of these pits, even under the constant rain of biogenic debris from the overlying waters. These authors calculate the likely flow rate of the waters to be approximately 2 to $20 \mathrm{~m} \mathrm{yr}^{-1}$ under steady state conditions. Whether or not such flow really is steady state or episodic must depend on whether or not the conduits for flow are always open. It does seem likely that dissolution and resuspension of pelagic sediments that fall into the pit keep the pit relatively clear of loose sediments [Mayer, 1981].

[30] The series of pits located along a fault trace (Figure 6) is unrelated to the fractures caused by differential compaction. This leads us to believe that it is the creation of this conduit of permeability through the sedimentary aquatard that is the critical element in the formation of these sedimentary pits. Thus it is not the basement highs themselves acting as a "finger" of higher thermal conductivity in the sediments that is the critical factor, but rather it is the creation of a discharge pathway.

[31] It may be that the limits on pit occurrence and sediment thickness (Figure 8) give us a hint of what may control the distribution these pits. If the sediment cover is greater than $\sim 500 \mathrm{~m}$ in the valleys, the adjacent highs may also have been buried to the point that the discharge pathway is too long to maintain carbonate under saturation [Bekins et al., 2006] and effectively keep a pit open. In areas where sediments in valleys are thin $(<150 \mathrm{~m})$ outcrops are much more common (Figure 9) and the sedimentary aquatard is discontinuous. It may have little control over areas of discharge and recharge.
[32] In Figure $4 \mathrm{~b}$ the data give examples of several aspects of hydrothermal flow in sedimented regions. First, the subsurface (or "fossil") pit seen over the central basin high indicates that these pits can be shut off if the recharge zone is shut off, if the overlying sediment becomes thick enough that vertical conduits are blocked, or if there is some other significant change in sedimentary regime. In this case the uppermost sedimentary wedge extending into the basin is free of strong reflections and is similar to a thinner layer on the western side of the western plateau. This layer appears to result from a post-depositional reworking and westward transport of siliceous clay. At $8^{\circ} \mathrm{N}$ and water depths of $4900 \mathrm{~m}-5000 \mathrm{~m}$ all carbonate is likely to have been dissolved in such reworked sediments [Van Andel and Moore, 1974]. Thus maintaining an open pit by the mechanism of carbonate dissolution as hydrothermal waters flow upward and exit the pit [Bekins et al., 2006] would not have worked on these sediments.

[33] Second, there is a marked contrast in the two scarps seen in the swath map and crossed by the seismic line. The eastern scarp may be a more mature version of the western scarp. The basement ridge is exposed at its base and it has a relatively straight northward trend with only slight hints of cuspate indentations along its face. In contrast, along the western scarp another basement high lies buried at its foot and the scarp itself is formed by a whole series of overlapping pits. Finally, to the west of the western scarp, a field of six to eight pits give evidence for additional discharge that may have been sourced from the exposed basement $8 \mathrm{~km}$ to the east. This is comparable to the distance between recharge and discharge given by Bekins et al. [2006] in their examples. Thus Figure 4b may illustrate a complete hydrologic cycle of recharge (at the basement exposure) and discharge (from the pits to the west). If the basement outcrop at the easternmost scarp does represent a recharge zone created by exposure of the basement ridge (compare Figures $2 \mathrm{f}$ and $4 \mathrm{a}$ ), this indicates that some discharge zones can in time become recharge zones, and in the process can extend or rejuvenate local hydrothermal circulation cells. On the basis of heat flow measurements, Bekins et al. [2006] estimate that recharge and discharge cells should have dimensions of about $100 \mathrm{~km}^{2}$. As noted above, our estimate of pit density in the near equatorial region $\left(\sim 1\right.$ per $\left.210 \mathrm{~km}^{2}\right)$ is probably conservative. The density of recharge areas may be the controlling factor. Our estimate of outcrop density is 1 per $630 \mathrm{~km}^{2}$. If we assume each 
outcrop to be a point source with radial outflow in the crust, this average would allow such flow to have a radius of about $14 \mathrm{~km}$. This is within the range of convection cells dimensions used in modeling such flow; however, the nonrandom nature of outcrop and pit occurrence should be remembered along with the caution voiced by Fisher [2004] that the simple models used to date (as well as the broad scale averages presented here) may not accurately reflect the natural systems.

[34] It will take a detailed study of heat flow patterns around such features as described here and perhaps drilling into the sediments and crustal rocks around them to fully test our hypothesis of formation and to document the impact of such flow. If we are correct, the implication is that the proposed widespread hydrothermal flow in the older ocean crust has identifiable, focused discharge vents in some regions. This gives new impetus to the careful examination of such features in the search for more constrained models of hydrothermal flow. Such investigations may also help us evaluate many of the unknowns concerning the impact of this flow on the chemical weathering of the upper ocean crust [Bickle and Elderfield, 2004] and on the ecology of the sub seafloor microbial community.

\section{Acknowledgments}

[35] The authors wish to thank the officers and crew of the R/V Roger Revelle for a most enjoyable and productive expedition AMAT 03. We also acknowledge the excellent technical support for coring, imaging of the seafloor, and seismic data acquisition that we received on this cruise. Support for this research came from NSF OCE-0451291, NERC NE/C508985/1, and individual support from Stockholm University. Reviewers (both formal and informal) of this manuscript have contributed substantially to its development and we gratefully acknowledge their suggestions. We particularly thank Barbara Bekins and her coauthors for their helpful discussions.

\section{References}

Anderson, R. N., M. A. Hobart, and M. G. Langseth (1979), Geothermal convection through ocean crust and sediments in the Indian Ocean, Science, 204, 828-832.

Baker, P. A., P. M. Stout, M. Kastner, and H. Elderfield (1991), Large-scale lateral advection of seawater through oceanic crust in the central equatorial Pacific, Earth Planet. Sci. Lett., $105,522-533$.

Bekins, B. A., A. J. Spivack, E. E. Davis, and L. A. Mayer (2006), TI: Prolonged exposure of basement edifices caused by dissolution of biogenic ooze by hydrothermal venting, Eos Trans. AGU, 87(52), Fall Meet. Suppl., Abstract V13A-0641.

Bickle, M., and H. Elderfield (2004), Hydrothermal fluxes in a global context, in Hydrogeology of the Ocean Lithosphere, edited by E. Davis and H. Elderfield, pp. 677-690, Cambridge Univ. Press, New York.

Caress, D. W., and D. N. Chayes (1996), Improved processing of Hydrosweep DS multibeam data on the R/V Ewing, Mar. Geophys. Res., 18, 631-650.

Davis, E. E., and K. Becker (2004), Observations of temperature and pressure: Constraints on ocean crustal hydrologic state, properties, and flow, in Hydrology of the Oceanic Lithosphere, edited by E. E. Davis and H. Elderfield, pp. 225-271, Cambridge Univ. Press, New York.

D'Hondt, S. L., et al. (2003), Leg summary, Proc. Ocean Drill. Program Initial Rep., 201, 1-81.

Elderfield, H., C. G. Wheat, M. J. Mottl, C. Monnin, and B. Spiro (1999), Fluid and geochemical transport through oceanic crust: A transect across the flank of the Juan de Fuca Ridge, Earth Planet. Sci. Lett., 172, 151-165.

Fisher, A. T. (2004), Rates of flow and patterns of fluid circulation, in Hydrogeology of the Ocean Lithosphere, edited by E. Davis and H. Elderfield, pp. 337-375, Cambridge Univ. Press, New York.

Fisher, A., and K. Becker (2000), Channelized fluid flow in oceanic crust reconciles heat-flow and permeability data, Nature, 403, 71-74.

Fisher, A. T., et al. (2003a), Hydrothermal recharge and discharge across $50 \mathrm{~km}$ guided by seamounts on a young ridge flank, Nature, 421, 618-621.

Fisher, A. T., C. A. Stein, R. N. Harris, K. Wang, E. A. Silver, M. Pfender, M. Hutnak, A. Cherkaoui, R. Bodzin, and H. Villinger (2003b), Abrupt thermal transition reveals hydrothermal boundary and role of seamounts within the Cocos Plate, Geophys. Res. Lett., 30(11), 1550, doi:10.1029/ 2002GL016766.

Hammerstad, E., F. Pohner, F. Parthiot, and J. Bennett (1991), Field testing of a new deep water multibeam echo sounder, in Oceans '91, pp. 743-749, Inst. of Electr. and Electron. Eng., New York.

Harrington, P. K. (1985), Formation of pockmarks by porewater escape, Geo Mar. Lett., 5, 193-197.

Hovland, M., J. V. Gardner, and A. G. Judd (2002), The significance of pockmarks to understanding fluid flow processes and geohazards, Geofluids, 2, 127-136.

Kastner, M., and M. D. Rudnicki (2004), Ridge flank sediment-fluid interactions, in Hydrogeology of the Ocean Lithosphere, edited by E. Davis and H. Elderfield, pp. 534-571, Cambridge Univ. Press, New York.

Mayer, L. (1981), Erosional troughs in deep-sea carbonates and their relationship to basement structure, Mar. Geol., 39, 59-80.

Mitchell, N. C. (1998), Modeling Cenozoic sedimentation in the central equatorial Pacific and implications for true polar wander, J. Geophys. Res., 103, 17,749-17,766.

Oyun, S., H. Elderfield, and G. P. Klinkhammer (1995), Strontium isotopes in pore waters of eastern equatorial Pacific sediments: Indicators of seawater advection through oceanic crust and sediments, Proc. Ocean Drill. Program Sci. Results, 138, 813-820.

Ross, D. A., E. Uchupi, E. P. Summerhayes, D. E. Koelsch, and E. M. El Shazly (1978), Sedimentation and structure of the Nile Cone and Levant Platform area, in Sedimentation in Submarine Canyons, Fans, and Trenches, edited by D. J. Stanley and G. Keeling, pp. 261-275, Dourden, Hutchinson, and Ross, Stroudsburg, Pa.

Sclater, J. G., J. Crowe, and R. N. Anderson (1976), On the reliability of ocean heat flow averages, J. Geophys. Res., 81, 2997-3006. 
Shipley, T. H., E. L. Winterer, M. Goud, S. J. Hills, C. V. Metzler, C. K. Paull, and J. T. Shay (1985), Seabeam bathymetric and water-gun seismic reflection surveys in the equatorial Pacific, Initial Rep. Deep Sea Drill. Proj., 85, 825837.

Spinelli, G. A., E. R. Giambalvo, and A. T. Fisher (2004), Sediment permeability, distribution, and influence on fluxes in oceanic basement, in Hydrogeology of the Ocean Lithosphere, edited by E. Davis and H. Elderfield, pp. 414-447, Cambridge Univ. Press, New York.

Staudigel, H., and H. Furnes (2004), Microbial mediation of crust alteration, in Hydrogeology of the Ocean Lithosphere, edited by E. Davis and H. Elderfield, pp. 606-624, Cambridge Univ. Press, New York.

Stein, C. A., and S. Stein (1992), A model for the global variation in oceanic depth and heat flow with lithospheric age, Nature, 359, 123-129.
Van Andel, T. H., and T. C. Moore Jr. (1974), Cenozoic calcium carbonate distribution and calcite compensation depth in the central equatorial Pacific Ocean, Geology, 2, 87-92.

Von Herzen, R. P. (2004), Geothermal evidence for continuing hydrothermal circulation in older ( $>60$ M.y.) ocean crust, in Hydrogeology of the Ocean Lithosphere, edited by E. Davis and H. Elderfield, pp. 414-450, Cambridge Univ. Press, New York

Walker, J. R., and H. R. Ensminger (1970), Effects of diapirism on sedimentation in the Gulf of Mexico, Am. Assoc. Pet Geol. Bull., 54, 2058-2069.

Wessel, P., and W. H. F. Smith (1991), Free software helps map and display data, Eos Trans. AGU, 72, 441-445-446.

Wheat, C. G., and M. J. Mottl (2004), Geochemical fluxes through mid-ocean ridge flanks, in Hydrogeology of the Ocean Lithosphere, edited by E. Davis and H. Elderfield, pp. 627-658, Cambridge Univ. Press, New York. 